\title{
Standardized Patients or Conventional Lecture for Teaching Communication Skills to Undergraduate Medical Students: A Randomized Controlled Study
}

\author{
Pierre A. Geoffroy ${ }^{1,2,3 *} \bowtie$, Julie Delyon ${ }^{1,4,5 *}$, Marion Strullu ${ }^{1,6}$, Alexy Tran Dinh ${ }^{1,7}$, Henri Duboc ${ }^{1,8,9}$, \\ Lara Zafrani ${ }^{1,10,11}$, Isabelle Etienne ${ }^{1}$, Michel Lejoyeux ${ }^{1,2}$, Pierre-François Ceccaldi ${ }^{1,12}$, \\ Patrick Plaisance ${ }^{1,13}$, and Hugo Peyre ${ }^{1,14}$ \\ ${ }^{1}$ iLumens Diderot Simulation Health Center, Paris University, Paris, France \\ ${ }^{2}$ Department of Psychiatry and Addiction Medicine, AP-HP, Hopital Bichat-Claude Bernard, Paris, France \\ ${ }^{3}$ NeuroDiderot, Inserm, Paris University, Paris, France \\ ${ }^{4}$ Université de Paris; INSERM U976, Team 1, HIPI, Paris, France \\ ${ }^{5}$ Department of Dermatology, AP-HP Hôpital Saint Louis, Paris, France \\ ${ }^{6}$ Service d'hémato-Immunologie Pédiatrique, Hôpital Robert Debré, AP-HP, Paris, France \\ ${ }^{7}$ Department of Anesthesiology and Critical Care Medicine, AP-HP, University Hospital Bichat-Claude Bernard, Paris, France \\ ${ }^{8}$ INSERM U1149, Centre de Recherche sur I'Inflammation, Université Paris Diderot, Paris, France \\ ${ }^{9}$ Department of Gastroenterology, Louis Mourier Hospital, AP-HP, Paris, France \\ ${ }^{10}$ INSERM U976, HIPI, Paris, France \\ ${ }^{11}$ Department of Intensive Care Medicine, AP-HP Hôpital Saint Louis, Paris, France \\ ${ }^{12}$ HUPNVS, Paris University, Beaujon Hospital, Department of Obstetrics and Gynecology, Clichy, France \\ ${ }^{13}$ Department of Emergency Medicine, Lariboisière University Hospital, AP-HP, Paris, France \\ ${ }^{14}$ Service de Psychiatrie de l'Enfant et de l'Adolescent, Hôpital Robert Debré, Paris, France
}

Objective The conduct of a medical interview is a challenging skill, even for the most qualified physicians. Since a training is needed to acquire the necessary skills to conduct an interview with a patient, we compared role-play with standardized patients (SP) training and a conventional lecture for the acquisition of communications skills in undergraduate medical students.

Methods An entire promotion of third year undergraduate medical students, who never received any lessons about communications skills, were randomized into 4 arms: 1) SP 2 months before the testing of medical communications skills (SP); 2) conventional lecture 2 months before the testing (CL); 3 ) two control groups (CG) without any intervention, tested either at the beginning of the study or two months later. Students were blindly assessed by trained physicians with a modified 17-items Calgary-Cambridge scale.

Results 388 students (98.7\%) participated. SP performed better than CL, with significant statistical differences regarding 5 skills: the use of open and closed questions, encouraging patient responses, inviting the patient to clarify the missing items, encouraging of the patient's emotions, and managing the time and the conduct of the interview. The SP group specifically improved communications skills between the SP training and testing sessions regarding 2 skills: the use of open and closed questions and encouraging patient responses. No improvements in communications skills were observed in CG between the two time points, ruling out a possible time effect.

Conclusion Role-play with standardized patients appears more efficient than conventional lecture to acquire communication skills in undergraduate medical students.

Psychiatry Investig 2020;17(4):299-305

Key Words Undergraduate medical education, Communication training, Standardized patient.

\footnotetext{
Received: September 29, 2019 Revised: November 12, 2019 Accepted: December 27, 2019

$\square$ Correspondence: Pierre A. Geoffroy, MD, PhD

Department of Psychiatry and Addictive Medicine, University Hospital Bichat-Claude Bernard, 46 rue Henri Huchard, Paris 75018, France

Tel: +33 (0)1 402582 62, E-mail: pierre.a.geoffroy@gmail.com

*These authors contributed equally to this work.

(c) This is an Open Access article distributed under the terms of the Creative Commons Attribution Non-Commercial License (https://creativecommons.org/licenses/by-nc/4.0) which permits unrestricted non-commercial use, distribution, and reproduction in any medium, provided the original work is properly cited
} 


\section{INTRODUCTION}

The conduct of a medical interview is a challenging skill, even for the most qualified physicians. Several objectives should be achieved in the same time, such as gathering precise and valid medical information, establishing a climate of trust and empathy, and providing diagnostic and therapeutic strategies. ${ }^{1}$ A set of interpersonal skills is required during the medical interview to obtain the confidence of the subject. The building of patient confidence is a process called "engagement" and results to what is traditionally called an alliance. In order to succeed the engagement process, the physician will need interpersonal skills that can be trained such as providing empathy, sense of security, authenticity, and competence. ${ }^{1}$ It is now established that a good communication between physicians and patients can lead to better patient compliance, and better satisfaction with the care received. ${ }^{2}$ However communication skills -defined here as interpersonal skills- need to be trained as other medical skills, as initial but also continuing training for physicians, otherwise they will deteriorated. ${ }^{3}$

Since a practice is needed to acquire the necessary skills during the interview with a patient, most medical schools now integrate specialized training to teach communication skills. ${ }^{4}$ Training strategies include oral presentation, modeling by watching others (reality or video), small group discussions, peer role-play and role play with standardized patients (SP). ${ }^{5}$ Increasing attention exists regarding SP programs that have proven efficacy in teaching communication skills to students. ${ }^{5-7}$ SP can be played by actors, real patients or physicians, who are trained to follow predefined scenarios and to provide standardized responses. SP programs integrate the opportunity of standardization between sessions. The reproducibility of the sessions allows to examine communication skills with a good reliability between students. ${ }^{8}$
The use of such interactive trainings have been compared to more conventional didactic methods like learning in a manual, and have proved superiority in the acquisition of communication skills. ${ }^{9}$ However, up to date, no studies assessed the efficacy of role-play with SP in teaching communication skills versus a lecture, which is the very most used didactic method. ${ }^{10}$ Moreover, such study is expected as the interactive training programs based on role-play and SP are shown to be effective but are more time and cost consuming than conventional lectures. ${ }^{11}$ In this context, we decided to develop in our university a simulation-based education program conducted in a dedicated simulation center that promotes simulation in healthcare education. SP programs to train communication skills were developed for undergraduate medical students. We conducted a randomized study to compare role-play with SP training and a conventional lecture for the acquisition of communication skills in undergraduate medical students. Our hypothesis was that students trained with SP would have higher ratings in objective communication skill measures assessed with the Calgary modified guide.

\section{METHODS}

\section{Population of students}

The study was approved by the local education authorities (Paris 7 UFR Medecine).

An entire promotion of third year undergraduate medical students who never received any lessons about medical communication skills were randomized into 4 arms: 1) SP training 2 months before the testing of medical communications skills (SP group); 2) conventional lecture training 2 months before the testing (CL group); 3) two control groups (CG) without any intervention (Figure 1).

Testing of communication skills was performed by a stan-

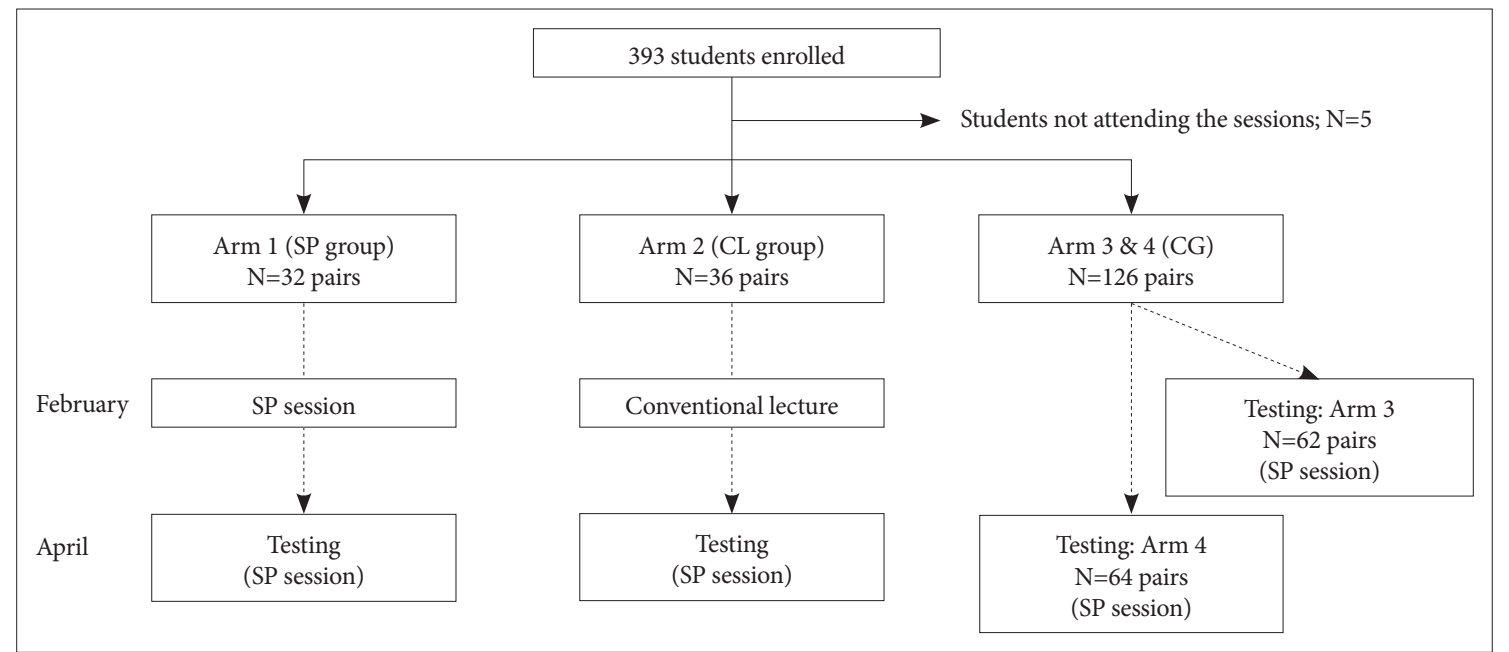

Figure 1. Flowchart of students enrolled and randomized into four arms. CL: conventional lecture, CG: control groups, SP: standardized patients. 
dardized-patient session, 2 months after the initial training protocol for SP and CL group. Scenarios were different in March and April to avoid a learning bias in the SP group (Supplementary Materials in the online-only Data Supplement). For control groups 1 and 2, medical communications skills were assessed by a standardized-patient session at two time points: either at the beginning of the study (control group 1) or two months after (control group 2), to take into account the effects of bedside teaching in hospitals (Figure 1).

\section{Standardized patients' sessions}

Students were divided in groups of 4 . Each group of 4 trainees was under the supervision of one tutor, which was a graduated medical doctor. Two SP were interviewed at each session. Two trainees were conducting the interviews of the first SP, while the tutor was taking notes outside of the room behind a one-way glass, with the 2 other trainees observing the relational skills of their colleagues. The position of the trainees was switched for the interview of the second SP. All students were randomly paired and given a short preparation time before conducting the interview together. At the end of the inter- view, trainees were given feedback by the tutors, the SP and the observing trainees. Scenarios were based on typical presentations of common conditions (Supplementary Materials in the online-only Data Supplement). Students had only access to information regarding the current situation of each SP. The actors were trained graduated medical doctors. Their scenario included a detailed medical information about the patient background, lifestyle and history to ensure a good reproducibility between groups [scenario are available in Supplementary Materials (in the online-only Data Supplement)].

\section{Conventional lecture}

The conventional lecture was a 2 hours lecture made by a trained psychiatrist (PAG) in a classroom, using slides projected on a large screen. The focus of the lecture was about communications skills and reviewed the main interpersonal skills and how to improve them. Students could ask questions in an interactive manner, and the course was illustrated by real-life clinical situations. In addition, the lecture included the main items of the Calgary Cambridge guide. All students from the CL group attended the course.

Table 1. Modified Calgary guide interview, translated from French

\begin{tabular}{|c|c|c|c|}
\hline \multirow{2}{*}{ Tasks } & \multicolumn{3}{|c|}{ Item observed } \\
\hline & No & In part & Yes \\
\hline \multicolumn{4}{|l|}{ Initiating the session } \\
\hline \multicolumn{4}{|l|}{1 - Greets patient by name } \\
\hline \multicolumn{4}{|l|}{2 - Introduces self and role } \\
\hline \multicolumn{4}{|l|}{3 - Identifies the patient's problems with appropriate opening question } \\
\hline \multicolumn{4}{|l|}{ Gathering information exploration of patient's problems } \\
\hline \multicolumn{4}{|l|}{4 - Encourages patient to tell the story of the problem } \\
\hline \multicolumn{4}{|l|}{5 - Does not interrupt the patient } \\
\hline \multicolumn{4}{|c|}{6 - Uses open and closed questioning technique, synthesizing closed questions from information already gathered } \\
\hline \multicolumn{4}{|c|}{7 - Facilitates patients responses verbally e.g., use of encouragement, silence, repetition, paraphrasing, interpretation } \\
\hline \multicolumn{4}{|l|}{8 - Invites patient to clarify/provide further information } \\
\hline \multicolumn{4}{|l|}{ Explain and planify } \\
\hline \multicolumn{4}{|l|}{9 - Avoids or adequately explains jargon } \\
\hline \multicolumn{4}{|l|}{10 - Establishes dates and/or times and sequence of events } \\
\hline \multicolumn{4}{|l|}{ Building relationship } \\
\hline \multicolumn{4}{|l|}{11 - Encourages patient to express feelings } \\
\hline \multicolumn{4}{|l|}{12 - Overtly acknowledges patient's views, feelings or predicament } \\
\hline \multicolumn{4}{|l|}{13 - Explores patient's beliefs and worries regarding cause of the problems discussed } \\
\hline \multicolumn{4}{|l|}{ Providing structure } \\
\hline \multicolumn{4}{|l|}{14 - Summarizes patient information gathered at the end of a specific line of inquiry } \\
\hline \multicolumn{4}{|l|}{15 - Attends to time management of interview } \\
\hline \multicolumn{4}{|l|}{ Closing the session } \\
\hline \multicolumn{4}{|l|}{16 - Asks if any corrections, questions or other items to discuss } \\
\hline 17 - Final check that patient agrees with summary and confirms understanding & & & \\
\hline
\end{tabular}




\section{Assessment of communication skills}

Tutors were blinded from students' arms. At the end of each session, the tutors rated the communication skills following 17 items of a modified version of the Calgary-Cambridge guide. ${ }^{8,12}$ Criteria were translated and modified to focus on concrete items that could easily be rated during the interviews (Table 1). Each criteria could be rated as not performed (score $=0$ ), present but insufficient (score $=1$ ) or correctly performed (score $=2$ ). The sum of scores were calculated for each paired student group. The principal judgment criteria of efficacy was the global score on the modified Calgary-Cambridge scale. Secondary criteria included self-rating scale assessing the pedagogical interest of each training method, on a scale ranging from 0 (no pedagogical interest) to 10 (the best pedagogical interest).

\section{Statistical analyses}

Mean and standard deviations were calculated for interview performances within groups. These performances assessed with the modified Calgary guide interview (Table 1) followed normal distributions and comparisons between groups were made using a t-test. A p value $<0.05$ was considered statistically significant. Statistics were made using SPSS 22.0 (IBM Corp., Armonk, NY, USA).

\section{RESULTS}

\section{Population}

During the 2018-2019 academic year, 393 third-year undergraduate medical students were included at the Paris Diderot University. 388 students (98.7\%) as well as 32 graduated medical doctors (tutors and actors) participated to the program of training communication skills.

In the SP groups, students were 32 pairs at the February training, and 18 pairs at the April testing. For the group that assisted to a conventional lecture in February and were trained with SP in April, they were 36 pairs. The two SP controlled groups of February were 62, and those in April were 64. Finally, 5 students did not assist from none of the groups (Figure 1).

Table 2. Comparison of interview performances of medical students after a conventional lecture or a training with standard patients, assessed with the modified Calgary guide interview

\begin{tabular}{|c|c|c|c|}
\hline & $\begin{array}{l}\text { Conventional lecture group } \\
\text { Mean (SD) }\end{array}$ & $\begin{array}{l}\text { Standardized-patient group } \\
\text { Mean (SD) }\end{array}$ & $\begin{array}{l}\text { t-test (2-tailed) } \\
\mathrm{p}\end{array}$ \\
\hline Global score & $25.25(6.40)$ & $27.72(3.34)$ & 0.068 \\
\hline 1. Names the patient & $1.56(0.73)$ & $1.17(0.99)$ & 0.15 \\
\hline 2. Introduces him/her-self & $1.78(0.54)$ & $1.83(0.38)$ & 0.67 \\
\hline 3. Identifies consultation motive & $1.78(0.59)$ & $1.89(0.32)$ & 0.38 \\
\hline 4. Encourages the patient to tell his/her problem history & $1.78(0.48)$ & $1.94(0.24)$ & 0.095 \\
\hline 5. Don't interrupt & $1.75(0.60)$ & $1.56(0.86)$ & 0.40 \\
\hline 6. Uses open and closed questions & $1.75(0.55)$ & $2.00(0.00)$ & $0.01^{*}$ \\
\hline $\begin{array}{l}\text { 7. Encourages patient responses through acquiescence, repetition, } \\
\text { paraphrases }\end{array}$ & $1.58(0.65)$ & $2.00(0.00)$ & $<0.0005^{*}$ \\
\hline 8. Invites the patient to clarify the missing items & $1.50(0.70)$ & $1.83(0.38)$ & $0.028^{*}$ \\
\hline 9. Avoid medical jargon, or take the time to explain it & $1.78(0.54)$ & $1.83(0.38)$ & 0.67 \\
\hline $\begin{array}{l}\text { 10. Establishes the continuation of the support (sequence of } \\
\text { examinations for example) }\end{array}$ & $1.31(0.67)$ & $1.56(0.62)$ & 0.18 \\
\hline 11. Encourages expression of the patient's emotions & $1.19(0.71)$ & $1.67(0.59)$ & $0.014^{*}$ \\
\hline 12. Recognizes the patient's feelings, hear his/her questions & $1.47(0.61)$ & $1.44(0.62)$ & 0.88 \\
\hline 13. Explores the patient's beliefs or representations about his illness & $1.00(0.59)$ & $1.11(0.76)$ & 0.59 \\
\hline 14. Synthesizes and reformulates patient responses & $1.28(0.74)$ & $1.50(0.51)$ & 0.21 \\
\hline 15. Can manage the time and the conduct of the interview & $1.33(0.68)$ & $1.78(0.43)$ & $0.005^{*}$ \\
\hline $\begin{array}{l}\text { 16. Ask the patient for any questions or comments before closing } \\
\text { the interview }\end{array}$ & $1.28(0.88)$ & $1.28(0.89)$ & 1.00 \\
\hline $\begin{array}{l}\text { 17. Ensures that the patient understands the diagnosis and/or } \\
\text { subsequent care }\end{array}$ & $1.14(0.79)$ & $1.33(0.77)$ & 0.39 \\
\hline
\end{tabular}

*significant results 


\section{Interview performances of medical students after a conventional lecture or a training with standardized patients}

The SP group demonstrated better performances than students that were first trained with a conventional lecture, with 5 out of the 17 skills that were particularly improved by the SP training: the use of open and closed questions, encouraging patient responses, inviting the patient to clarify the missing items, encouraging of the patient's emotions, and managing the time and the conduct of the interview (Table 2).

\section{Interview performances of medical students after training with standardized patients}

SP group students improved communications skills between the 2 SP sessions (February and April). Statistically significant differences regarding 2 out of the 17 skills were observed: the use of open and closed questions, and encouraging patient responses (Table 3).

To take into account the effects of the hospital bedside teaching that occurred at the same time, control groups tested with SP sessions in February ( $\mathrm{n}=62)$ and April $(\mathrm{n}=64)$ were compared. They did not show any improvement in communications skills over time, ruling out a possible time effect (results not shown).

\section{Self assessment of pedagogical interest by students}

Students who had both the conventional lecture and the SP testing (CL group) found a clear better pedagogic interest of the SP training versus the conventional lecture (Student's $\mathrm{t}=$ -7.56; $\mathrm{p}<0.001$ ) (Figure 2).

\section{DISCUSSION}

In this randomized controlled study, we report a comparison between conventional lecture and SP session in teaching

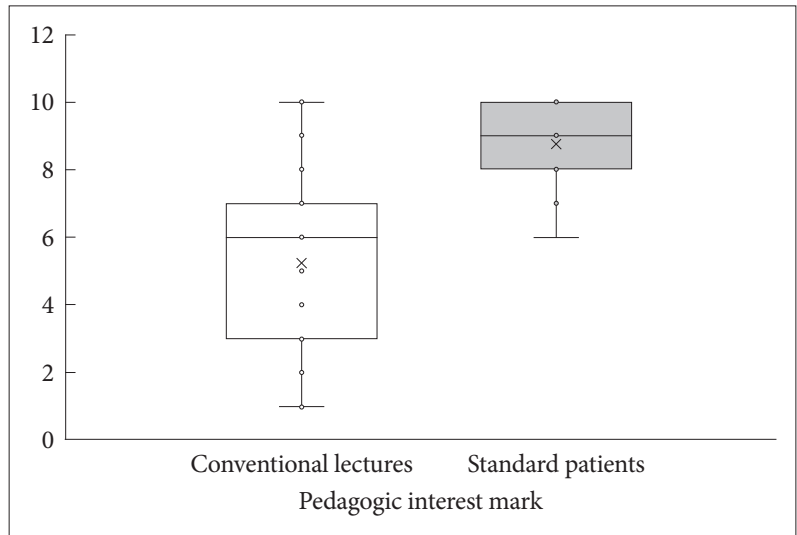

Figure 2. Pedagogic interest assessed by students from 0 to 10 .

Table 3. Performances of SP group over time, assessed with the modified Calgary guide interview

\begin{tabular}{|c|c|c|c|}
\hline & $\begin{array}{c}\text { SP group after } \\
\text { SP training session } \\
\text { Mean }(\mathrm{SD})\end{array}$ & $\begin{array}{c}\text { SP group at } \\
\text { testing session } \\
\text { Mean }(\mathrm{SD})\end{array}$ & $\begin{array}{c}\text { t-test (2-tailed) } \\
\mathrm{p}\end{array}$ \\
\hline Global score & $25.44(5.49)$ & $27.72(3.34)$ & 0.074 \\
\hline 1. Names the patient & $1.59(0.71)$ & $1.17(0.99)$ & 0.12 \\
\hline 2. Introduces him/her-self & $1.78(0.42)$ & $1.83(0.38)$ & 0.66 \\
\hline 3. Identifies consultation motive & $1.71(0.52)$ & $1.89(0.32)$ & 0.16 \\
\hline 4. Encourages the patient to tell his/her problem history & $1.84(0.45)$ & $1.94(0.24)$ & 0.30 \\
\hline 5. Don't interrupt & $1.56(0.76)$ & $1.56(0.86)$ & 0.98 \\
\hline 6. Uses open and closed questions & $1.68(0.57)$ & $2.00(0.00)$ & $0.001^{*}$ \\
\hline 7. Encourages patient responses through acquiescence, repetition, paraphrases & $1.53(0.67)$ & $2.00(0.00)$ & $<0.0005^{*}$ \\
\hline 8. Invites the patient to clarify the missing items & $1.59(0.67)$ & $1.83(0.38)$ & 0.11 \\
\hline 9. Avoid medical jargon, or take the time to explain it & $1.78(0.49)$ & $1.83(0.38)$ & 0.68 \\
\hline 10. Establishes the continuation of the support (sequence of examinations for example) & $1.37(0.79)$ & $1.56(0.62)$ & 0.38 \\
\hline 11. Encourages expression of the patient's emotions & $1.57(0.67)$ & $1.67(0.59)$ & 0.29 \\
\hline 12. Recognizes the patient's feelings, hear his/her questions & $1.41(0.67)$ & $1.44(0.62)$ & 0.84 \\
\hline 13. Explores the patient's beliefs or representations about his illness & $1.00(0.84)$ & $1.11(0.76)$ & 0.64 \\
\hline 14. Synthesizes and reformulates patient responses & $1.31(0.74)$ & $1.50(0.51)$ & 0.30 \\
\hline 15. Can manage the time and the conduct of the interview & $1.56(0.56)$ & $1.78(0.43)$ & 0.14 \\
\hline 16. Ask the patient for any questions or comments before closing the interview & $1.03(0.78)$ & $1.28(0.89)$ & 0.34 \\
\hline 17. Ensures that the patient understands the diagnosis and/or subsequent care & $1.18(0.78)$ & $1.33(0.77)$ & 0.53 \\
\hline
\end{tabular}

*significant results 
communication skills to undergraduate medical students. Our results showed that teaching with SP was associated with improved communication skills as compared to a conventional lecture. Moreover, we observed a significant improvement between the first and the second SP sessions, suggesting that despite a daily active bedside teaching, interviews with SP still provided additional training and contribute to the acquisition of relevant communication skills.

Among strengths of our study, the whole promotion of students was included, whereas most studies were based only on volunteers among medical students, which may have led to selection biases. ${ }^{9}$ Moreover, students were randomized between groups, and the supervisors were blinded to student's arms. All these conditions were required to avoid confounding factors such as imbalance between skills of students before starting the program, which are recognized major biases of such pedagogic studies. ${ }^{9}$

Previous studies reported that lecture methods were considered too passive to properly develop the acquisition of communication skills, as compared to active methods such as SP. ${ }^{13,14}$ In our study, students benefited from teaching with SP in the objective acquisition of skills, but also provided positive feedback about the pedagogical interest of the training. All students were successively interviewers and observers participating in the supervision of the interview. Thus, the trainees were encouraged to analyze their strengths and weakness following the Calgary Cambridge scale, which contributed to the acquisition of skills. Moreover, the availability of graduated physicians as tutors facilitated the interactivity in the groups and the experience sharing between students and tutors. This positive feedback has been linked to effective learning ${ }^{15}$ and could contribute to a sustainable retention of skills, although our study did not assess the long term benefit of the program.

Some limits should be acknowledged. First, our data were collected immediately at the end of the SP sessions, and so the sustainability of acquired communication skills can not be assessed from this study. We cannot conclude regarding the longterm benefit from this short-term program. Moreover, some studies suggested that longer training programs (more than one day) would be more effective than shorter, ${ }^{5}$ and we did not compare different SP trainings according to their duration. The best results were from practical training programs as role play, that combined a didactic component with practical rehearsal and feedback. ${ }^{16}$ Probably the best training program would include both lessons and SP session. ${ }^{17}$ Moreover, flipped classroom has also demonstrated very interesting teaching results, with growing popularity, and could be combined or compared to SP in future studies. ${ }^{18}$ Third, the evaluation of paired students may also have altered the results. Nevertheless, to ensure comparability between groups, even in the smallest group, students were trained by two to avoid confusing factors between arms, and so this may not have impacted the efficacy comparison. Finally, we may wonder whether the SP teaching program would have been more useful if it had been scheduled before reaching a real patient's bedside (in second year), and if it could be repeated in higher grade students to teach more delicate skills such as teaching bad news. But although the implementation of the SP teaching program has been considered a success, the high cost of running such a program, as well as the necessity to recruit a large number of actors and tutors, may represent a limit to the generalization of this teaching approach.

Regarding cost assessments, significant human resources were necessary to carry out this educational program, but students reacted favorably to the SP training sessions and their learning significantly improved after training. Consequently, we concluded that Kirkpatrick's level 2 was reached ${ }^{19}$ (accounting for the acquisition of skills) strongly encouraging us to continue this program in our University. Interestingly, SP training shows efficacy in teaching the communication skills in foreign medical students, too. ${ }^{20}$ Future researches are also expected to compare different methods to evaluate reliably communication skills, ${ }^{21-23}$ as well as assessing the impact of these training on health outcomes. ${ }^{4}$

Teaching communication skills with standardized patients programs was more efficient than a traditional lecture in undergraduate medical students. Nevertheless, the long-term sustainability of such acquisition and its consequences in building the patient-physician relationship need to be assessed.

\section{Supplementary Materials}

The online-only Data Supplement is available with this article at https://doi.org/10.30773/pi.2019.0258.

\section{Acknowledgments}

None.

\section{Conflicts of Interest}

The authors have no potential conflicts of interest to disclose.

\section{Author Contributions}

Conceptualization: Pierre A. Geoffroy, Julie Delyon, Hugo Peyre. Data curation: Pierre A. Geoffroy, Isabelle Etienne. Formal analysis: Pierre A. Geoffroy, Julie Delyon, Hugo Peyre. Investigation: Pierre A. Geoffroy, Julie Delyon, Marion Strullu, Alexy Tran Dinh, Henri Duboc, Lara Zafrani, Hugo Peyre. Methodology: Pierre A. Geoffroy, Julie Delyon, Pierre-François Ceccaldi, Patrick Plaisance, Hugo Peyre. Project administration: Pierre A. Geoffroy, Julie Delyon, Pierre-François Ceccaldi, Patrick Plaisance, Hugo Peyre. Supervision: Michel Lejoyeux, Pierre-François Ceccaldi, Patrick Plaisance. Validation: Pierre-François Ceccaldi, Patrick Plaisance. Visualization: Pierre A. Geoffroy. Writing-original draft: Pierre A. Geoffroy, Julie Delyon. Writing — review \& editing: Marion Strullu, Alexy Tran Dinh, Henri Duboc, Lara Zafrani, Isabelle Etienne, Michel Lejoyeux, PierreFrançois Ceccaldi, Patrick Plaisance, Hugo Peyre. 


\section{ORCID iDs}

Pierre A. Geoffroy

Julie Delyon

Alexy Tran Dinh

Pierre-François Ceccaldi

Hugo Peyre
https://orcid.org/0000-0001-9121-209X https://orcid.org/0000-0002-4557-3377

https://orcid.org/0000-0003-4361-5104

https://orcid.org/0000-0003-4716-9199

https://orcid.org/0000-0001-8757-0783

\section{REFERENCES}

1. Micoulaud-Franchi JA, Geoffroy PA, Amad A, Quiles C. Le boucher du Prince Wen-houei. De l'art médical du recueil sémiologique valide en psychiatrie [Internet]. Annales Médico-psychologiques, revue psychiatrique, 2016. Available at: http://linkinghub.elsevier.com/retrieve/ pii/S0003448716000913. Accessed May 3, 2016.

2. Tamblyn R, Abrahamowicz M, Dauphinee D, Wenghofer E, Jacques A, Klass D, et al. Physician scores on a national clinical skills examination as predictors of complaints to medical regulatory authorities. JAMA 2007;298:993-1001.

3. Keifenheim KE, Teufel M, Ip J, Speiser N, Leehr EJ, Zipfel S, et al. Teaching history taking to medical students: a systematic review. BMC Med Educ 2015; 15:159.

4. Modi JN, Anshu -, Chhatwal J, Gupta P, Singh T. Teaching and assessing communication skills in medical undergraduate training. Indian Pediatr 2016;53:497-504.

5. Berkhof M, van Rijssen HJ, Schellart AJM, Anema JR, van der Beek AJ. Effective training strategies for teaching communication skills to physicians: an overview of systematic reviews. Patient Educ Couns 2011; 84:152-162.

6. Bosse HM, Nickel M, Huwendiek S, Jünger J, Schultz JH, Nikendei C. Peer role-play and standardised patients in communication training: a comparative study on the student perspective on acceptability, realism, and perceived effect. BMC Med Educ 2010;10:27.

7. Ainsworth MA, Rogers LP, Markus JF, Dorsey NK, Blackwell TA, Petrusa ER. Standardized patient encounters. A method for teaching and evaluation. JAMA 1991;266:1390-1396.

8. Taylor S, Bobba S, Roome S, Ahmadzai M, Tran D, Vickers D, et al. Simulated patient and role play methodologies for communication skills training in an undergraduate medical program: Randomized, crossover trial. Educ Health (Abingdon) 2018;31:10-16.

9. Lane C, Rollnick S. The use of simulated patients and role-play in communication skills training: a review of the literature to August 2005. Patient Educ Couns 2007;67:13-20.

10. Roche AM, Eccleston P, Sanson-Fisher R. Teaching smoking cessation

skills to senior medical students: a block-randomized controlled trial of four different approaches. Prev Med 1996;25:251-258.

11. Bosse HM, Nickel M, Huwendiek S, Schultz JH, Nikendei C. Cost-effectiveness of peer role play and standardized patients in undergraduate communication training. BMC Med Educ 2015;15:183.

12. Kurtz SM, Silverman JD. The Calgary-Cambridge Referenced Observation Guides: an aid to defining the curriculum and organizing the teaching in communication training programmes. Med Educ 1996;30: 83-89.

13. Aspegren K. BEME Guide No. 2: Teaching and learning communication skills in medicine-a review with quality grading of articles. Med Teach 1999;21:563-570.

14. Rees C, Sheard C, McPherson A. Medical students' views and experiences of methods of teaching and learning communication skills. Patient Educ Couns 2004;54:119-121.

15. Bruen C, Kreiter C, Wade V, Pawlikowska T. Investigating a self-scoring interview simulation for learning and assessment in the medical consultation. Adv Med Educ Pract 2017;8:353-358.

16. Gysels M, Richardson A, Higginson IJ. Communication training for health professionals who care for patients with cancer: a systematic review of effectiveness. Support Care Cancer 2004;12:692-700.

17. Rao JK, Anderson LA, Inui TS, Frankel RM. Communication interventions make a difference in conversations between physicians and patients: a systematic review of the evidence. Med Care 2007;45:340-349.

18. Persky AM, McLaughlin JE. The flipped classroom - from theory to practice in health professional education. Am J Pharm Educ 2017;81: 118.

19. Yardley S, Dornan T. Kirkpatrick's levels and education "evidence." Med Educ 2012;46:97-106.

20. Zhang J, Cheng M, Guo N, Xing A, Xu L. "Standardized patients" in teaching the communication skill of history-taking to four-year foreign medical undergraduates in the department of obstetrics and gynaecology. BMC Med Educ 2019;19:108.

21. Radziej K, Loechner J, Engerer C, Niglio de Figueiredo M, Freund J, Sattel H, et al. How to assess communication skills? Development of the rating scale ComOn Check. Med Educ Online 2017;22:1392823.

22. Roh H, Park KH, Park SY. Verbal communication of students with high patient-physician interaction scores in a clinical performance examination assessed by standardized patients. Korean J Med Educ 2017; 29:241-251.

23. Park KH, Park SG. The effect of communication training using standardized patients on nonverbal behaviors in medical students. Korean J Med Educ 2018;30:153-159. 


\section{SUPPLEMENTARY MATERIALS}

\section{French Scenario Used during Standardized-Patient Sessions}

\section{Scénario 1-cas assis}

Objectifs pédagogies spécifiques:

- Attitude empathique vis-à-vis des inquiétudes du patient concernant les limitations de son activité professionnelle et sportive.

- Ne pas donner d'informations erronées sur l'hypothèse de rupture des ligaments croisés.

Briefing des étudiants (à lire par l'enseignant-superviseur devant la chambre).

Vous êtes externe au service d'accueil des urgences. Emmanuel (ou Emmanuelle; M/F) Prichard, âgé de 31 ans a été admis pour une douleur du genou droit.

On l'a installé dans le box des urgences.

Il faudrait clarifier l'histoire de la maladie et recueillir le mode de vie et les antécédents personnels et familiaux.

Le médecin sénior viendra l'examiner avec vous dans un $2^{\text {ème }}$ temps (donc pas d’examen physique à faire).

\section{Scenario de l'enseignant-acteur}

Vous êtes Emmanuel (ou Emmanuelle; M/F) Prichard, âgé de 31 ans.

Motif de consultation: Vous avez une douleur/boiterie au genou droit depuis 1 mois.

Mode de vie: Vous êtes policier professionnel, sportif de compétition (judo, ski). Marié avec une fille de 2 ans (Amélie).

Histoire de la maladie: La douleur est apparue brutalement pendant un entrainement de judo (pas de choc direct ni de chute): violente douleur du genou, gonflement et craquement perçu. Depuis 1 mois, marche avec boiterie, sensation d'instabilité du genou et douleur EVA 5/10. Vous n'avez pas consulté de médecin avant en pensant que cela passerait, mais la douleur s’est accentuée et vous avez préféré venir aux urgences.

Antécédents personnels: Otites à répétition pendant l'enfance avec pose de yoyos. Une fracture du nez lors d'une bagarre quand vous étiez adolescent [ces antécédents sont banals mais il est important que les étudiants apprennent à les recueillir brièvement, précisément et avec tact; idem pour les antécédents familiaux].

Antécédents familiaux: Votre mère a été traitée efficacement pour un cancer du sein par chimiothérapie il y a 4-5 ans.

Plaintes à mettre en avant pendant la consultation (et à introduire pendant le recueil du mode vie, histoire de la maladie et antécédents)

1) Inquiétude concernant le fait d’arrêter son activité professionnelle. (« je ne peux pas laisser mes collègues de la brigade! »). 2) Inquiétude concernant le fait d’arrêter son activité sportive ( « je vais devenir nul si je ne pratique pas régulièrement le judo », «bientôt la saison de ski et je me suis déjà engagé pour des slaloms », " je vais prendre du poids si je ne fais pas de sport »). 3) Le patient craint une rupture des ligaments ou une fracture [ne pas attendre plus de létudiant que "je vais voir avec mon senior» ou «on va attendre des examens supplémentaires "]. 


\section{Scenario 2-Cas allongé}

Briefing des étudiants (à lire par l'enseignant-superviseur devant la chambre).

Vous êtes externe au service de pneumologie. Dominique Vaal (M/F), âgé de 21 ans a été admis il y a 3 jours via les urgences pour une pneumopathie qui évolue favorablement avec un traitement antibiotique.

Etudiant dans une grande école de commerce, il a fait une pneumopathie d'inhalation dans un contexte divresse aigue. On vient d’avoir les résultats de son bilan hépatique qui montre une cytolyse hépatique et une cholestase biologique.

Depuis aujourd'hui, il semble avoir repris ses esprits. Voilà son dossier médical. Votre médecin sénior vous demande d’aller le voir pour recueillir le mode de vie et les antécédents personnels et familiaux ainsi que l'interroger sur ses consommations de toxiques. Le médecin sénior viendra lexaminer avec vous dans un $2^{\text {ème }}$ temps (donc pas d’examen physique à faire).

\section{Scenario de l'enseignement-acteur}

Vous êtes Dominique Vaal (M/F) âgé de 21 ans.

Motif de consultation: Vous ne vous souvenez plus du déroulement des évènements. Demander au médecin de vous raconter ce qui sest passé.

Mode de vie: Etudiant en école de commerce, vous préférez la fête aux examens, et de toutes les façons vous avez trop de retard sur les partiels pour valider votre année. Vous avez échoué votre premier trimestre.

Histoire de la maladie: Vous avez tendance au « Binge Drinking» ces temps-ci (2-3 ivresses par semaine [ne donner des estimations précises que si létudiant les demande clairement], consommez du cannabis avec les autres (pas de consommation solitaire, n’achète pas, banaliser avec des « tout le monde fume », « ça devrait être légal»).

Antécédents personnels: Asthme allergique, eczéma de contact, allergie aux chats [ces antécédents sont banals mais il est important pour les étudiants d’apprendre à les recueillir brièvement, précisément et avec tact].

Antécédents familiaux: Frère schizophrène mort lan passé par suicide.

Plaintes à mettre en avant pendant la consultation (et à introduire pendant le recueil du mode vie, histoire de la maladie et antécédents): 1) Inquiétudes sur la toxicité au long cours: («Mon foie va bien?»; «Est ce que les anomalies sur la prise de sang peuvent être dues à l'alcool? »). 2) Inquiétudes concernant la suite de son cursus ("Faut que j’y retourne, déjà que mon année est mal partie »; «Les profs vont m’en vouloir ». 3) Inquiétudes concernant son intégration sociale: «Qui m’a amenée ici? », «Est ce que les copains de la corpo sont venus me voir quand jétais là?»). 4) Rapidement vous reprenez du poil de la bête et demandez à savoir quand vous pourrez consommer à nouveau parce que « ce nest pas grave, je suis étudiant et tout le monde fait comme cela ». 5) Le poumon ne vous gêne pas, les infections ça se traite avec des antibiotiques, la preuve, elle n’a plus de fièvre.

Lieu: Patient allongé dans un lit d’hôpital. 


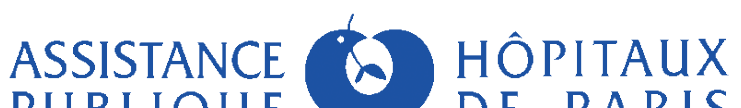 PUBLIQUE DE PARIS}

\section{Service de Pneumologie de l'Hôpital Pajol}

\section{Rue du Département \\ 75018 Paris}

\section{Dossier médical}

Patient: Dominique Vaal (M)

Né le 25 mai 1997

NIP: 51271664

Admis à $8 \mathrm{~h}$ au SAU (il y a 3 jours).

- Amené au SAU par des collègues de son école de commerce avec lesquels il a fait la fête la veille.

- Plaie du cuir chevelu $\rightarrow 3$ points de suture.

- Altération de la conscience (alcoolémie à l'admission à 2,6 g/l).

- Dyspnée, fièvre $\left(39^{\circ}\right)$ et toux productive avec expectoration putride. Très probable pneumopathie d'inhalation. Décision de transfert dans notre Service de Pneumologie le jour même.

\section{Dans le Service de Pneumologie.}

- Pneumopathie d'inhalation. Introduction d'un traitement antibiotique par Augmentin (1gx3 par jour). Bonne évolution des paramètres respiratoires.

- Patient désorienté.

- Plusieurs visites de ses amis au cours de l'hospitalisation.

- Résultats du bilan hépatique: cytolyse hépatique (ASAT et ALAT>20 fois la normale) et cholestase biologique (bilirubine augmentée). En cours d'exploration. 


\section{Scenario 3-Cas allongé}

\section{Objectifs pédagogies spécifiques:}

- Adapter son vocabulaire et ses explications aux capacités de compréhension du patient.

- Anamnèse de la consommation de toxiques.

- Ne pas donner d'informations erronées sur le rein unique (et attendre l'urologue).

\section{Briefing externe (à lire par le CCA-superviseur devant la chambre).}

Vous êtes externe aux urgences. Dominique (M/F) Duchemin, âgé de 29 ans, a été admis il y a 1 heure pour une colique néphrétique (BU positive, ASP et échographie rénale retrouvant un calcul dans l'uretère droit). Il était très douloureux à larrivée et a reçu des antalgiques qui lont bien soulagé. L'échographie a également révélé que le patient a un rein unique, non antérieurement connu. Lurologue de garde va passer pour donner son avis sur la prise en charge en urgence.

Linterrogatoire avait été sommaire du fait de la douleur. Maintenant qu’il est soulagé, votre interne vous demande d’aller ré-interroger le patient sur son mode de vie, ses antécédents et l'anamnèse (pas d’examen physique à faire).

\section{Scenario de l'enseignant-acteur}

Vous êtes Dominique (M/F) Duchemin âgé de 29 ans. [Patient qui ne comprend pas les termes techniques médicaux, ni les explications compliquées].

Histoire de la maladie: En rentrant du travail ce soir, vous avez brutalement présenté une douleur sur le côté droit du ventre, extrêmement intense. Cest la première fois que cela vous arrive. Vous êtes directement allé aux urgences où lon vient de vous diagnostiquer une colique "phréatique » (une sorte de petit caillou coincé dans votre ventre fait gonfler votre rein du côté droit). Vous avez reçu un bonus de morphine à larrivée, ce qui vous a bien soulagé. Le radiologue vous a dit plusieurs fois qu'il ne voyait pas grand chose parce qu'il y avait des « dépositions gazeuses » mais qu’il ne voyait pas le rein gauche. Vous êtes inquiet parce que vous avez vu que le radiologue était préoccupé mais n’avez pas compris où était le problème.

Mode de vie: Célibataire, sans enfant. Vous êtes employé de mairie affecté à lentretien des jardins. Tabagisme 15 cigarettes par jour. Consommation dalcool occasionnelle.

Antécédents médicaux et chirurgicaux personnels: Aucun.

Antécédents médicaux familiaux: Votre mère a eu des problèmes de rein à plusieurs reprises et va très bien.

\section{Plaintes à mettre en avant pendant la consultation:}

Est ce que c'est grave d’avoir une colique "phréatique »?

Pouvez-vous me dire ce qui va se passer maintenant?

Est-ce que je vais pouvoir rentrer chez moi?

Je n'ai pas compris le problème du rein à gauche? 


\section{Scénario 4-Cas assis}

\section{Objectifs pédagogiques spécifiques:}

- Attitude adaptée devant un patient impatient et banalisant la gravité du diagnostic.

- Ne pas donner d'informations erronées sur les examens complémentaires.

Briefing des étudiants (à lire par l'enseignant-superviseur devant la chambre).

Vous êtes externe au service des urgences de l'hôpital. Michel (Michelle, M/F) Drouillet, 33 ans est adressé(e) aux urgences par son médecin traitant pour une hépatite virale. Il/elle se gratte depuis 7 jours et ne dort plus.

Votre médecin sénior est parti sur un arrêt cardiaque, il en a pour longtemps et vous a demandé d’aller voir le/la patiente et « débrouiller le terrain », mais reviendra l'examiner plus tard (donc pas d'examen physique à faire).

\section{Scenario de l'enseignant-acteur}

Vous êtes Michel (Michelle, M/F) Drouillet âgé(e) de 33 ans.

Motif de consultation: Vous vous grattez depuis 7 jours et vous avez vu votre médecin traitant il y a 5 jours qui a prescrit des examens complémentaires.

Histoire de la maladie: Vous êtes parti en voyage au Laos et avez vadrouillé en mode « couleur locale », vous avez eu une " diarrhée cosmique », bu de leau pas claire et mangé dans les villages locaux, « mais les gens sont tellement gentils là bas... » vous avez fumé des trucs super trippants (sans vous rappeler des substances consommées) mais pas de substance IV. Vous navez pas fait les vaccins avant de partir parce que vous êtes plutôt « antivax ». Vous avez vu un médecin il y a 5 jours qui vous a prescrit une série d'examens.

Antécédents personnels: Appendicectomie, fracture du bras droit en 1992.

Traitements: AINS à dose importante pour des douleurs de genoux (travaille dans la restauration).

Antécédents familiaux: Aucun.

\section{Plaintes à mettre en avant pendant la consultation:}

$\rightarrow$ Vous êtes un peu impatient, ça fait $6 \mathrm{~h}$ que vous attendez, «c'est pas cool »: létudiant doit s'excuser, et expliquer qu'il est navré mais qu'il a eu des urgences vitales.

$\rightarrow$ L’étudiant doit vous demander de lui fournir lexamen complémentaires fait en ville que vous avez gardé dans votre poche: écho abdominale et bilan biologique: léchographie est normale, pas d’anomalie des voies biliaires. Pour le reste vous avez eu vos résultats sur smartphone et vous dites: «bah y avait une hépatite A j’ai vu sur internet ».

$\rightarrow$ Létudiant doit gérer en direct la découverte de léchographie: Le but est qu'il essaie de répondre au maximum de ses connaissances mais qu’il sache sarrêter: il doit savoir dire « Là je vais revenir après avoir montré tout cela à mon chef ». 